\title{
Purification and Properties of Glycerol Dehydrogenase from Candida valida
}

\author{
By GÖTZ GÄRTNER AND GERHARD KOPPERSCHLÄGER* \\ Institute of Physiological Chemistry, Karl-Marx-University Leipzig, DDR-7010 Leipzig, \\ Liebigstrasse 16, GDR
}

(Received 15 March 1984; revised 4 June 1984)

\begin{abstract}
Glycerol : NAD ${ }^{+}$2-oxidoreductase (EC 1.1.1.6) was purified to homogeneity from the nonmethylotrophic yeast Candida valida $\mathrm{H} 122$. Results of electrophoresis in polyacrylamide gels, gel filtration and ultracentrifugation were compatible with the enzyme's consisting of two subunits with a molecular weight 38000 . No heterogeneity was observed by isoelectric focusing. The $\mathrm{pH}$ optima were 10.0 for glycerol oxidation and 7.5 for dihydroxyacetone reduction. The $K_{\mathrm{m}}$ values for glycerol, dihydroxyacetone, NAD ${ }^{+}$and NADH were $5.8 \times 10^{-2} \mathrm{M}, 7.7 \times 10^{-4} \mathrm{M}$, $1.4 \times 10^{-4} \mathrm{M}$ and $4.8 \times 10^{-5} \mathrm{M}$, respectively. 1,2-Propanediol also served as substrate in the forward and DL-glyceraldehyde in the reverse reaction. The oxidation product of glycerol was identified as dihydroxyacetone. An ordered bi-bi mechanism was deduced from product-inhibition studies. Of several anions and cations tested, pyrophosphate and ammonium ions stimulated the dehydrogenating activity the most. 2-Mercaptoethanol, ethylene glycol and Tris inhibited activity; an inhibition was also observed by phosphorylated coenzymes and substrates. The purified enzyme, which is labile at low concentrations, was stabilized by the addition of neutralized filtrate from the culture liquid.
\end{abstract}

\section{INTRODUCTION}

Glycerol can be utilized as carbon source by diverse eukaryotic micro-organisms. In yeast the utilization of glycerol is initiated by phosphorylation (Gancedo et al., 1968; Sprague \& Cronan, 1977). Recently, an alternative route of glycerol metabolism and its regulation involving glycerol dehydrogenase as primary enzyme have been studied in Candida valida (Hofmann \& Babel, 1979) and Schizosaccharomyces pombe (May \& Sloan, 1981). In both species, dihydroxyacetone kinase activities were also demonstrated (Babel \& Hofmann, 1982; May et al., 1982), which apparently co-operate with the dehydrogenases. However, the dehydrogenases are not sufficiently characterized to allow one to understand their physiological function. The presence of glycerol dehydrogenase (EC 1.1.1.6) in Geotrichum candidum has also been shown recently, and two isoenzymes were isolated and characterized (Itoh, 1982). In this paper, the purification and properties of a $\mathrm{NAD}^{+}$-linked glycerol dehydrogenase from the non-methylotrophic strain Candida valida $\mathrm{H} 122$ are described.

\section{METHODS}

Organisms and growth conditions. Candida valida strain $\mathrm{H} 122$ was kindly provided by Professor H. A. Koch, Medical Academy, Erfurt, GDR. Cells were cultured at $30^{\circ} \mathrm{C}$ in Erlenmeyer flasks ( $100 \mathrm{ml}$ in $500 \mathrm{ml}$ flasks) on a shaker rotating at about 200 r.p.m. A medium (Reader, 1927) containing $0 \cdot 1 \%$ yeast extract and $2 \%(w / v)$ glycerol was used. The initial $\mathrm{pH}$ was adjusted to 5.5 with $2 \mathrm{M}-\mathrm{NaOH}$. Cells were harvested during the early stationary phase of growth by centrifugation.

Enzyme extraction and purification. All manipulations were carried out at $4{ }^{\circ} \mathrm{C}$. Cells $(30 \mathrm{~g}$ wet wt) were washed three times by resuspension and centrifugation with buffer $\mathrm{A}(50 \mathrm{~mm}$-potassium phosphate buffer, $\mathrm{pH} 7 \cdot 5,10 \mathrm{~mm}$ glycerol, $3 \mathrm{mM}-2$-mercaptoethanol), then resuspended to about $0.6 \mathrm{~g}$ wet wt $\mathrm{ml}^{-1}$ and passed twice through a chilled French pressure cell at $9.9 \mathrm{kN} \mathrm{m}^{-2}$. Cell debris was removed by centrifugation at $20000 \mathrm{~g}$ for $30 \mathrm{~min}$. The supernatant was supplemented with solid $\left(\mathrm{NH}_{4}\right)_{2} \mathrm{SO}_{4}$ up to $65 \%$ saturation, stirred for $\mathrm{I} h$ and then centrifuged at 
$20000 \mathrm{~g}$ for $30 \mathrm{~min}$. The precipitate was resuspended in an appropriate volume of buffer A supplemented with $1.2 \mathrm{M}-\left(\mathrm{NH}_{4}\right)_{2} \mathrm{SO}_{4}$ to give a final saturation of $40 \%$. The solution was stirred for $30 \mathrm{~min}$ and centrifuged at $25000 \mathrm{~g}$ for $30 \mathrm{~min}$. The supernatant was desalted on a Sephadex G-25 column equilibrated with buffer A containing $50 \mathrm{~mm}-\mathrm{KCl}$ and then applied to a column $(2.5 \times 20 \mathrm{~cm})$ of Servacel DEAE 23 SS equilibrated with the same buffer. The enzyme was eluted at a flow rate of $30 \mathrm{ml} \mathrm{h}^{-1}$ by a linear increase of $\mathrm{KCl}$ concentration from 50 to $250 \mathrm{mM}$ in a total buffer volume of $400 \mathrm{ml}, 9 \mathrm{ml}$ fractions being collected. Active fractions were pooled and concentrated to less than $10 \mathrm{ml}$ by ultrafiltration using stirred Amicon cells equipped with a Diaflo PM30 membrane. The concentrated enzyme was then chromatographed on a Sephadex G-150 column $(2.5 \times 100 \mathrm{~cm})$. Buffer B $(20 \mathrm{mM}-$ Tris/HCl buffer, $\mathrm{pH} 7.0$ at $25^{\circ} \mathrm{C}, 10 \mathrm{mM}$-glycerol, $3 \mathrm{~mm}$-2-mercaptoethanol) was pumped through the column at a rate of $10 \mathrm{ml} \mathrm{h}^{-1}$ and $2.5 \mathrm{ml}$ fractions were collected. The pooled active fractions were applied to a column $(2 \times$ $10 \mathrm{~cm}$ ) of calcium phosphate gel and the enzyme was eluted with a linear gradient of 0 to 50 mM-potassium phosphate in buffer $B$ (total volume of $50 \mathrm{ml}$ ). The combined active fractions were concentrated by vacuum dialysis (Collodion bags SM 13200; Sartorius) to more than $1 \mathrm{mg}$ protein $\mathrm{ml}^{-1}$. Enzyme was stored at $-15^{\circ} \mathrm{C}$ in buffer $\mathrm{B}$.

Enzyme assays and kinetic studies. The activity of glycerol dehydrogenase was measured at $25^{\circ} \mathrm{C}$ by following the change in absorbance of pyridine nucleotide at $340 \mathrm{~nm}$ with a Reaction Rate Analyzer (LKB) or a Unicam SP 1750. The reaction mixture of the routine assays contained: $100 \mathrm{~mm}$-sodium pyrophosphate (pH 9.5), $400 \mathrm{~mm}$ glycerol, $50 \mathrm{~mm}-\left(\mathrm{NH}_{4}\right)_{2} \mathrm{SO}_{4}$, and $1 \mathrm{~mm}-\mathrm{NAD}^{+}$. For measuring the reduction of dihydroxyacetone the assay mixture contained: $100 \mathrm{~mm}$-potassium phosphate $(\mathrm{pH} 7.5), 100 \mathrm{~mm}$-dihydroxyacetone, and $0.25 \mathrm{~mm}-\mathrm{NADH}$. The assay systems were tested for enzyme inactivation according to Selwyn (1965). One unit of enzyme activity was defined as the amount of enzyme which catalysed the conversion of $1 \mu \mathrm{mol}$ of substrate per minute at $25^{\circ} \mathrm{C}$. Specific activity was expressed as units ( $\mathrm{mg}$ protein $)^{-1}$. The apparent kinetic parameters were determined from initialvelocity measurements in the absence of products by using the direct linear plot as described by Eisenthal \& Cornish-Bowden (1974). The graphical representation of the kinetic data was performed according to Hanes (1932). The equilibrium constant, as defined by the equation $\mathrm{K}_{\mathrm{eq}}=\left(\mathrm{NADH}_{\mathrm{eq}} \times\right.$ dihydroxyacetone $\left._{\mathrm{eq}} \times \mathrm{H}^{+}\right)$/ $\left(\mathrm{glycerol}_{\mathrm{eq}} \times \mathrm{NAD}_{\mathrm{eq}}^{+}\right.$), was determined in $0 \cdot 1 \mathrm{M}$-sodium pyrophosphate buffer at proton concentrations ranging from $3.16 \times 10^{-8} \mathrm{M}$ to $3.16 \times 10^{-9} \mathrm{M}$ with $50 \mathrm{mM}$-glycerol, $0.2 \mathrm{mM}$-dihydroxyacetone, $0.5 \mathrm{mM}-\mathrm{NAD}^{+}$and $0.05 \mathrm{mM}-$ $\mathrm{NADH}$. Concentrations of reactants and products were calculated from the change in absorbance at $340 \mathrm{~nm}$ after equilibration, i.e. after incubation for $2 \mathrm{~h}$ at $25^{\circ} \mathrm{C}$.

Analytical methods. Polyacrylamide gel electrophoresis with a linear gradient of acrylamide ( 3 to $15 \%$, w/v) was performed as described by Kopperschläger et al. (1977). Enzyme activity in gels was localized by incubating the gel rods in the reaction mixture used for the determination of glycerol oxidation rate supplemented with $0 \cdot 15 \mathrm{~mm}-8$ dimethylamino-2,3-benzophenoxazine (Meldola Blue) and I mM-2-(4-iodophenyl)-3-(4-nitrophenyl)-5-phenyl-2Htetrazolium chloride (INT). Gel rods were developed by keeping in the dark at $25^{\circ} \mathrm{C}$ for 15 to $20 \mathrm{~min}$.

SDS-gel electrophoresis was carried out according to Weber \& Osborn (1969) using $10 \%(\mathrm{w} / \mathrm{v})$ acrylamide. The molecular weight standards were cytochrome $c(12400)$ and its cross-linked oligomers (25000 to 75000$)$.

For isoelectric focusing, glycerol dehydrogenase $(10 \mu \mathrm{g}$ protein per rod) was resolved in $5 \%(\mathrm{w} / \mathrm{v})$ polyacrylamide gel containing Pharmalyte ( $\mathrm{pH} 4$ to 6.5) according to Laas \& Fast-Johansson (1979). For determination of the $\mathrm{pH}$ gradient the gels were sliced into $3 \mathrm{~mm}$ pieces and crushed in $0.6 \mathrm{ml}$ distilled water (freshly boiled) per gel slice. After $30 \mathrm{~min}$ the $\mathrm{pH}$ and enzyme activity were measured. Control gels were stained with Coomassie Brilliant Blue G-250.

The molecular weight of glycerol dehydrogenase was estimated by gel filtration on Sephadex G-150 as described by Andrews (1964). For calibration the following marker proteins were used: aldolase (rabbit muscle), mol. wt 158000; bovine serum albumin, 68000; ovalbumin, 45000; chymotrypsinogen A, 25000; cytochrome $c, 12400$.

Sedimentation velocity experiments were carried out in $5 \mathrm{~mm}$-Tris/ $\mathrm{HCl}$ buffer $(\mathrm{pH} 7 \cdot 5$ ), containing $10 \mathrm{~mm}$ glycerol and $3 \mathrm{~mm}-2$-mercaptoethanol, at 50000 r.p.m. and $20^{\circ} \mathrm{C}$ with a Phywe Model U60L analytical ultracentrifuge (Phywe AG, Göttingen, FRG) using the UV optics. The apparent sedimentation coefficient was determined at $0.6 \mathrm{mg}$ protein $\mathrm{ml}^{-1}$. The molecular weight was roughly estimated from the equation, mol. wt $=6500$ $\left(s_{2(1+h}\right)^{3.2}$, according to Scrimgeour (1977).

Protein was measured by the method of Bradford (1976) using bovine serum albumin as the standard.

For reaction product analysis the glycerol oxidation was coupled to a $\mathrm{NAD}^{+}$-regenerating system. The reaction mixture contained in $2 \mathrm{ml}: 200 \mu \mathrm{mol}$ potassium phosphate buffer ( $\mathrm{pH} \mathrm{8.0),1} \mathrm{mmol} \mathrm{glycerol,} 1$ mmol sodium pyruvate, $240 \mu \mathrm{mol} \mathrm{NAD}{ }^{+}, 550$ units lactate dehydrogenase, 450 units purified glycerol dehydrogenase. After $1 \mathrm{~h}$ incubation at $30^{\circ} \mathrm{C}$ the reaction mixture was passed through a Sephadex G-10 column. The fractions containing product were applied to an Amberlite MB-2 column and eluted with distilled water. The break-through fraction was subjected to TLC on silica gel plates (Silufol, Kavalier, Czechoslovakia) using butanol/acetic acid/water (14:3:3, by vol.). Chromatograms were stained by vaporization of crystalline iodine.

Chemicals and prepared substances. Ethylene glycol, dihydroxyacetone, DL-glyceraldehyde, glycerol, DL-1,2propanediol, sugars and sugar alcohols were obtained from Merck. Other substrates, coenzymes, enzymes, Tris and Meldola Blue were from Boehringer; 2-mercaptoethanol, dithiothreitol, cysteine, reagents for electrophoresis, 
ion exchangers and human serum albumin were from Serva Feinbiochemica (Heidelberg, FRG); Pharmalyte (pH 4 to 6.5), Sephadex and Sepharose gels were from Pharmacia; Cibacron Blue F3G-A was from Ciba-Geigy. All other chemicals were of analytical grade. Tetraethylammonium hydroxide was prepared by passing the chloride through a Dowex SAR anion exchanger. Cibacron Blue F3G-A-Sephadex G-100 was prepared according to Böhme et al. (1972), calcium phosphate gel according to Koike \& Hamada (1971), and cytochrome $c$-oligomers as described by Dunker \& Kenyon (1976) for lysozyme. Boiled crude cell extract was obtained by boiling the extract for $5 \mathrm{~min}$ in a water bath. Denatured protein was removed by centrifuging at $25000 \mathrm{~g}$ for $30 \mathrm{~min}$.

Filtrate of culture liquid was prepared with a UM05 membrane (Amicon) and neutralized.

\section{RESULTS}

\section{Purification and stability of glycerol dehydrogenase}

A summary of a representative enzyme purification is presented in Table 1. The re-extraction of the ammonium sulphate precipitate with a solution of lower saturation (see Methods) gave higher purification than the usual salt fractionation. From the DEAE-cellulose column, glycerol dehydrogenase activity was eluted as a single peak at $0.13 \mathrm{M}-\mathrm{KCl}$ in buffer A. Gel filtration on Sephadex G-150 mostly resulted in an enzyme fraction consisting of one major band and a faint band of higher molecular weight, as indicated by polyacrylamide gel electrophoresis under nondenaturing conditions. Only the main band stained for enzyme activity. Finally the chromatography on calcium phosphate gel yielded a homogeneous preparation (Fig. 1), but the recovery from this step was only about $40 \%$ of the enzyme activity.

In solutions of purified enzyme with concentrations of $0.5 \mathrm{mg}$ protein $\mathrm{ml}^{-1}$ or less, the activity completely disappeared within 2 to 3 weeks after storage at $4{ }^{\circ} \mathrm{C}$ or $-15^{\circ} \mathrm{C}$. However, in the presence of $5 \%(\mathrm{v} / \mathrm{v})$ culture filtrate or boiled crude cell extract, more than $80 \%$ of enzyme activity remained. The fact that the culture filtrate and boiled crude extract were able to stabilize the purified enzyme was consistent with decreasing enzyme stability with increasing purity. Divalent cations added as chlorides were not required for stability $\left(\mathrm{Mg}^{2+}, \mathrm{Ca}^{2+}, \mathrm{Mn}^{2+}, \mathrm{Co}^{2+}\right.$, $\left.\mathrm{Zn}^{2+}, \mathrm{Cu}^{2+}, \mathrm{Fe}^{2+}\right)$. The freshly prepared medium for cultivation was not capable of stabilizing the enzyme. Apparently a hitherto unknown factor produced during fermentation was responsible for enzyme stabilization. The enzyme activity was also stable for 1 month at $-15^{\circ} \mathrm{C}$ in the presence of $10 \%(\mathrm{w} / \mathrm{v})$ Ficoll.

\section{Molecular weight and isoelectric point}

SDS-polyacrylamide gels showed one band with an apparent molecular weight of 38000 . The molecular weight of the native enzyme as determined by filtration on Sephadex G-150 was 76000. From comparing relative mobilities of glycerol dehydrogenase with those of human serum albumin and its oligomers in a gradient of polyacrylamide ( 3 to $15 \%, \mathrm{w} / \mathrm{v}$ ) under nondenaturing conditions a molecular weight of 80000 was calculated. In the analytical ultracentrifuge the isolated enzyme sedimented with an apparent sedimentation coefficient of $5 \cdot 2 \pm 0.3 \mathrm{~S}$. This value corresponded to an approximate molecular weight of 77000 when calculated by the equation according to Scrimgeour (1977). The enzyme therefore behaves as a dimer consisting of two equal subunits. Isoelectric focusing revealed one single band with a pI of 4.8 .

Table 1. Purification of $N A D^{+}$-linked glycerol dehydrogenase from Candida valida $H 122$

$\begin{array}{lcccccr}\quad \begin{array}{c}\text { Volume } \\ \text { Purification step }\end{array} & \begin{array}{c}\text { Protein } \\ (\mathrm{mg})\end{array} & \begin{array}{c}\text { Total } \\ \text { activity } \\ \text { (units) }\end{array} & \begin{array}{c}\text { Specific } \\ \text { activity } \\ \left(\text { units } \mathrm{mg}^{-1}\right)\end{array} & \begin{array}{c}\text { Yield } \\ (\%)\end{array} & \begin{array}{r}\text { Purifi- } \\ \text { cation } \\ \text { factor }\end{array} \\ \begin{array}{l}\text { Crude cell extract } \\ \text { (from 30 g wet cells) }\end{array} & 65 & 1150 & 2290 & 1 \cdot 98 & 100 & \\ \begin{array}{l}\text { Ammonium sulphate } \\ \text { Servacel DEAE 23 SS }\end{array} & 73 & 427 & 1920 & 4 \cdot 50 & 84 & 2 \cdot 3 \\ \begin{array}{l}\text { Sephadex G-150 } \\ \text { Calcium phosphate }\end{array} & 82 & 30 \cdot 0 & 1110 & 37 \cdot 0 & 49 & 18 \cdot 7 \\ & 15 & 7 \cdot 19 & 708 & 98 \cdot 5 & 31 & 49 \cdot 8 \\ & 24 & 1.05 & 297 & 282 & 13 & 142 \cdot 7\end{array}$




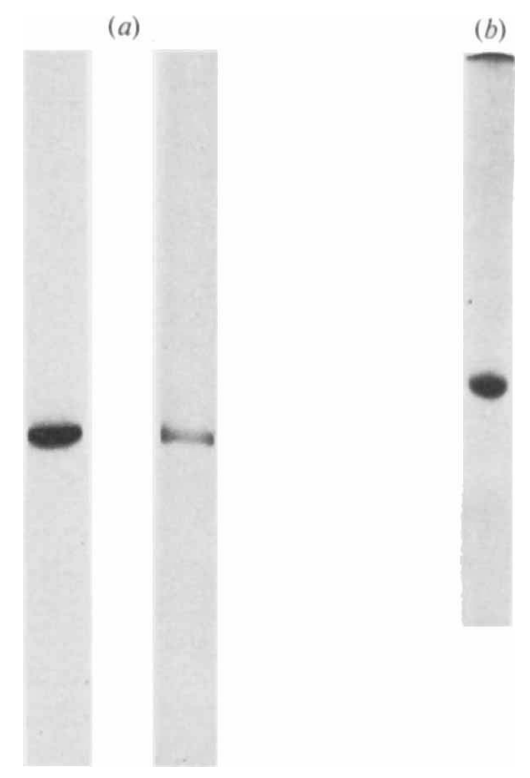

Fig. 1. Polyacrylamide gel electrophoresis of purified glycerol dehydrogenase from Candida valida H 122 after calcium phosphate gel chromatography. (a) $30 \mu \mathrm{g}$ Protein on a 3 to $15 \%$ gradient gel. Left gel: protein staining. Right gel: active staining. (b) $20 \mu \mathrm{g}$ Protein on an SDS gel.

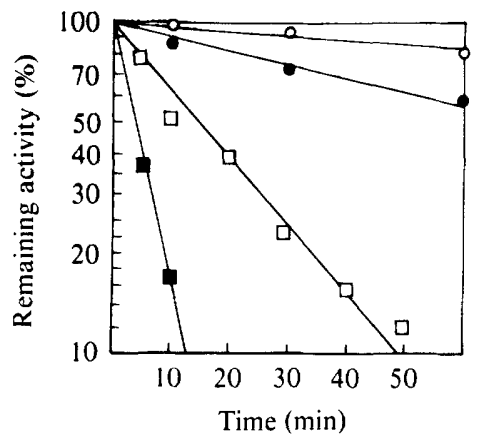

Fig. 2. Effect of temperature on the stability of glycerol dehydrogenase. Samples of $25 \mu \mathrm{g}$ enzyme in $0.5 \mathrm{ml} 0.02 \mathrm{M}$-potassium phosphate buffer ( $\mathrm{pH} 7.5$ ) containing $10 \mathrm{~mm}$-glycerol and $3 \mathrm{mM}-2$-mercaptoethanol were incubated at $40^{\circ} \mathrm{C}(\mathrm{O}), 50^{\circ} \mathrm{C}(\mathrm{O}), 55^{\circ} \mathrm{C}(\square), 60^{\circ} \mathrm{C}(\square)$ and at various times samples were assayed for remaining activity. $100 \%$ activity corresponds to 14 units $\mathrm{ml}^{-1}$.

\section{Effect of $\mathrm{pH}$ and temperature on enzyme activity and stability}

Oxidation reaction was maximum between $\mathrm{pH} 9.5$ and 10.5 in $0.1 \mathrm{M}$-pyrophosphate buffer, reduction reaction with dihydroxyacetone between $\mathrm{pH} 7.5$ and 8.5 in $0.1 \mathrm{M}$-phosphate buffer. Rates decreased more rapidly at the alkaline $\mathrm{pH}$. Alkaline buffers with $\mathrm{pH}$ values above 10 gave rise to other non-enzymic reactions and made the measurement of initial velocities difficult. In $0 \cdot 1 \mathrm{M}$-tetraethyl ammonium chloride/tetraethylammonium hydroxide buffer the $\mathrm{pH}$ profile for glycerol oxidation was shifted to a lower $\mathrm{pH}$ range with an optimum around $\mathrm{pH} 8 \cdot 0$. Glycerol dehydrogenase was most stable at $\mathrm{pH} 7.5$.

The enzyme had a temperature optimum at $36^{\circ} \mathrm{C}$. Thermostability of the purified enzyme is demonstrated in Fig. 2. 2-Mercaptoethanol had little protective effect against thermal inactivation. At $40^{\circ} \mathrm{C}$ after $2 \mathrm{~h}$ the remaining activities in the presence and absence of 2 -mercaptoethanol were $75 \%$ and $65 \%$, respectively. 
Table 2. Kinetic parameters for glycerol dehydrogenase

Values were obtained from appropriate replots of primary plots with varied concentration of the first substrate at various fixed concentrations of the second substrate. Maximum velocities are expressed as maximum specific activities.

\section{Substrate}

Glycerol

$\mathrm{NAD}^{+}$

Dihydroxyacetone

NADH
$K_{\mathrm{m}}$

(M)

$5.80 \times 10^{-2}$

$1.44 \times 10^{-4}$

$7.70 \times 10^{-4}$

$4.80 \times 10^{-5}$
$K_{\text {i }}$

(M)

$1.09 \times 10^{-3}$
$2.50 \times 10^{-5}$
$V_{\max }$

[units (mg protein $)^{-1}$ ]

448

442

202

206

\section{Influence of ions}

The effects of several monovalent cations on glycerol oxidation were assayed at $\mathrm{pH} 9 \cdot 5 . \mathrm{NH}_{4}^{+}$ gave rise to the highest extent of activity. At concentrations of $50 \mathrm{mM}$ or higher, the activation effects of several chloride salts were as follows: $\mathrm{NH}_{4}^{+}>\mathrm{K}^{+}>\mathrm{Na}^{+}>\mathrm{N}\left(\mathrm{C}_{2} \mathrm{H}_{5}\right)_{4}^{+}$. No detectable effect was produced by a series of divalent cations $\left(\mathrm{Mn}^{2+}, \mathrm{Zn}^{2+}, \mathrm{Mg}^{2+}, \mathrm{Ca}^{2+}, \mathrm{Co}^{2+}, \mathrm{Fe}^{2+}\right)$ when added as chlorides at concentrations of 0.1 and $1 \mathrm{mM}$ in pyrophosphate buffer. The influence of various anions on the enzyme activity was estimated using sodium salts. At pH 9.5 maximum activity was obtained in pyrophosphate buffer. Half-maximum velocity was already observed at $0 \cdot 3 \mathrm{~mm}$-sodium pyrophosphate. Generally, the enzyme was more active in the presence of multivalent anions (citrate, phosphate, sulphate) in comparison with monovalent anions (acetate, chloride). Optimal conditions for activity measurement were found at 30 to $60 \mathrm{~mm}$-ammonium sulphate in $0 \cdot 1 \mathrm{M}$-pyrophosphate buffer.

\section{Kinetic studies}

Initial-velocity measurements revealed typical sets of primary plots for an enzyme that obeyed the equation:

$$
v=\frac{V_{\max }[\mathrm{A}][\mathrm{B}]}{K_{\mathrm{ia}} K_{\mathrm{b}}+K_{\mathrm{a}}[\mathrm{B}]+K_{\mathrm{b}}[\mathrm{A}]+[\mathrm{A}][\mathrm{B}]}
$$

where $V_{\text {max }}$ is the maximum initial velocity, $K_{\mathrm{a}}$ and $K_{\mathrm{b}}$ are Michaelis constants for the substrates $\mathrm{A}$ and $\mathrm{B}$, and $K_{\mathrm{ia}}$ is the dissociation constant for the E-A complex (according to the nomenclature of Cleland, 1963). From these initial-velocity measurements, kinetic parameters for glycerol oxidation and dihydroxyacetone reduction were determined (Table 2).

Product inhibition by NADH was competitive with respect to $\mathrm{NAD}^{+}($Fig. $3 a)$. Dihydroxyacetone at subsaturating glycerol concentration $(0.2 \mathrm{M})$ with $\mathrm{NAD}^{+}$as variable substrate gave rise to mixed inhibition (Fig. $3 b$ ). When glycerol was varied at $1 \mathrm{mM}-\mathrm{NAD}^{+}$, dihydroxyacetone revealed a mixed type of inhibition (Fig. $3 c$ ). Such an inhibition pattern was consistent with the compulsory-order ternary-complex mechanism. The observed substrate inhibition (not shown) which occurred at more than $0.5 \mathrm{M}$-glycerol was in accord with this type of reaction.

The average equilibrium constant value $\left(K_{\text {eq }}\right)$ obtained from five individual determinations was $6.3 \times 10^{-12} \pm 2 \cdot 2 \times 10^{-12} \mathrm{M}$. This value was similar to that of $10.4 \times 10^{-12} \mathrm{M}$, as calculated from the kinetic constants by using the Haldane relationship.

\section{Substrate and coenzyme specificity}

In Table 3 the combinations of compounds tested as substrates and the pyridine nucleotides are summarized. The enzyme was found to exhibit a rather narrow substrate specificity. 1,2Propanediol was more rapidly dehydrogenated than glycerol due to the higher affinity $\left(K_{\mathrm{m}}^{1.2-P r o p a n e d i o l} 3 \times 10^{-3} \mathrm{M}\right)$. In the reverse reaction, dihydroxyacetone was more active than DLglyceraldehyde. The apparent $K_{\mathrm{m}}$ value for DL-glyceraldehyde $\left(6.2 \times 10^{-3} \mathrm{M}\right)$ was eightfold higher. The oxidation product of glycerol was identified as dihydroxyacetone by TLC (see 

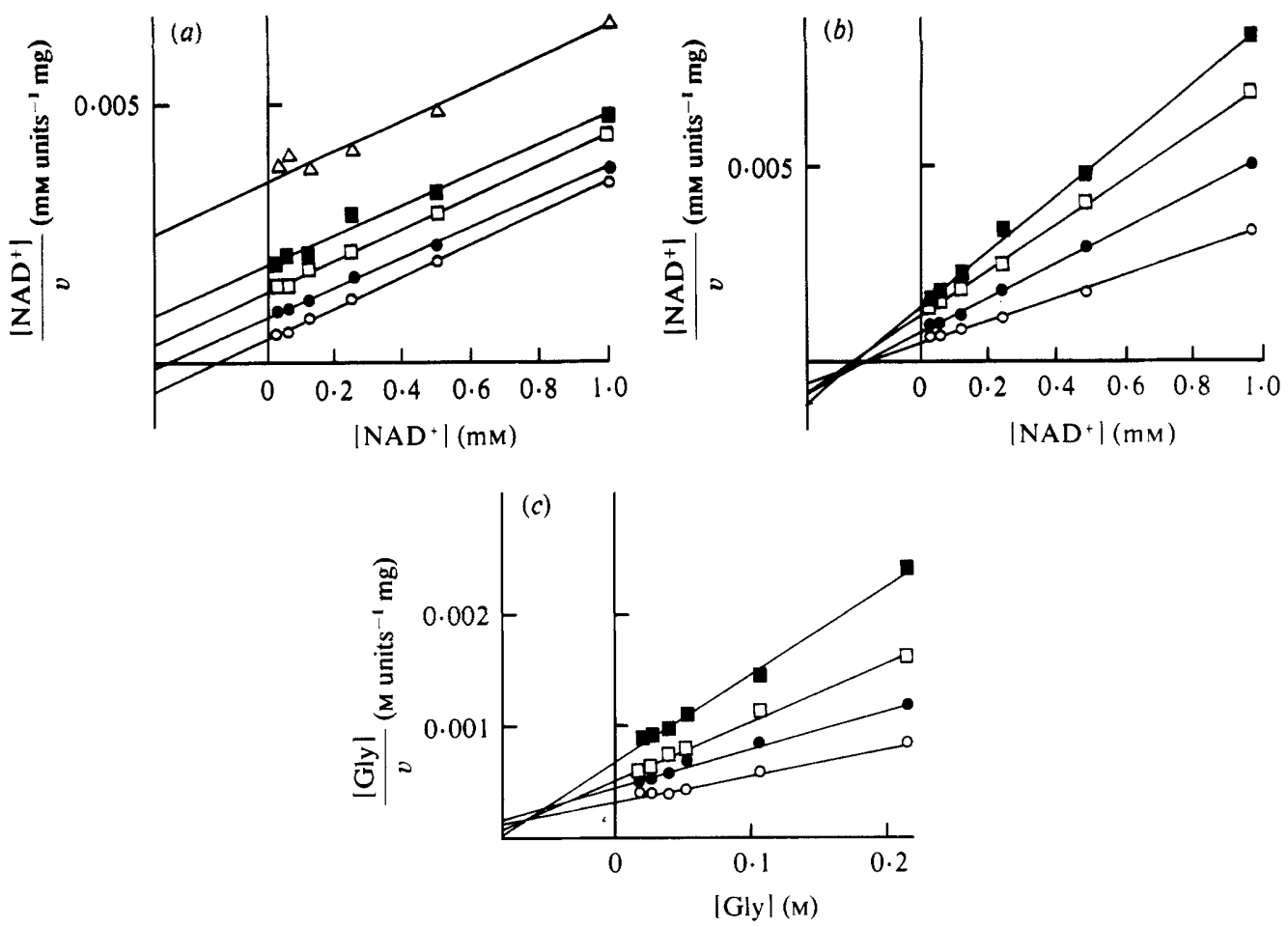

Fig. 3. Product inhibition of glycerol dehydrogenase at pH 8.5. (a) Inhibition by NADH with $\mathrm{NAD}^{+}$as variable substrate at constant glycerol (202 mM). Fixed NADH levels were $0.034 \mathrm{~mm}(0), 0.068 \mathrm{~mm}$ $(\square), 0.136 \mathrm{~mm}(\square), 0.272 \mathrm{mM}(\triangle)$ and none $(O)$. (b) Inhibition by dihydroxyacetone under conditions as indicated in $(a)$. Fixed dihydroxyactone levels were $0.76 \mathrm{~mm}(\bigcirc), 1.89 \mathrm{mM}(\square), 3.79 \mathrm{~mm}$ $(\mathbb{D})$ and none $(O)$. (c) Inhibition by dihydroxyacetone with glycerol as variable substrate at constant $\mathrm{NAD}^{+}$concentration $(1 \mathrm{~mm})$. Fixed dihydroxyacetone levels were $0.53 \mathrm{~mm}(\odot), 1.07 \mathrm{~mm}(\square), 4.27 \mathrm{mM}$ (घ) and none (O).

Methods). Phosphorylated substrates were inactive, as also were NADP ${ }^{+}$and NADPH. On the other hand, glycerol 3-phosphate, dihydroxyacetone phosphate, NADP ${ }^{+}$and NADPH were effective inhibitors. Inhibition data yielded values of $I_{0.5}$ for these compounds of $130,1.9,5$ and $0 \cdot 19 \mathrm{~mm}$, respectively.

Table 3. Substrate specificity of glycerol dehydrogenase for dehydrogenation and reduction

Determinations were made with $1 \mathrm{mM}^{-\mathrm{NAD}^{+}}$or NADP ${ }^{+}$and $0.25 \mathrm{~mm}-\mathrm{NADH}$ or NADPH under standard assay conditions (see Methods). No activity in the forward reaction was found with the following compounds: methanol, ethanol, 1-propanol, ethylene glycol, meso-erythritol, ribitol, xylitol, Dsorbitol, D-mannitol, D-glucose, L-lactate, L-glycerol 3-phosphate, D-glucose 6-phosphate, D-fructose 6phosphate, D-glyceraldehyde 3-phosphate. No activity in the reverse reaction was found with the following compounds: D-ribose, D-xylose, D-xylulose, D-fructose, D-mannose, D-galactose, acetone, acetaldehyde, pyruvate, D-glycerate 1,3-diphosphate and dihydroxyacetone phosphate.

\begin{tabular}{lccccc}
\cline { 4 - 5 } \multicolumn{1}{c}{ Substrate } & $\begin{array}{c}\text { Concn } \\
(\mathrm{mM})\end{array}$ & $\mathrm{NAD}^{+}$ & $\mathrm{NADP}^{+}$ & $\mathrm{NADH}$ & NADPH \\
Glycerol & 200 & 100 & 0 & & \\
1,2-Propanediol & 100 & 130 & 0 & & \\
Dihydroxyacetone & 100 & & & 100 & 0 \\
DL-Glyceraldehyde & 100 & & & 33 & 0
\end{tabular}




\section{Effect of various reagents on enzyme activity}

2-Mercaptoethanol, Tris and ethylene glycol showed strong inhibition of the enzyme activity $\left(I_{0.5} 0 \cdot 3,2\right.$ and $4 \mathrm{mM}$, respectively). Furthermore, the enzyme was slightly inhibited by cysteine and dithiothreitol but not affected by glutathione. $N$-Ethylmaleimide inactivated the enzyme rapidly $\left(I_{0.5} 0.2 \mathrm{mM}\right)$, indicating the presence of essential thiol groups.

\section{DISCUSSION}

The non-methylotrophic strain Candida valida $\mathrm{H} 122$ proved to be a suitable source for the purification of glycerol dehydrogenase. The enzyme represented approximately $0.7 \%$ of the extracted cell protein when the cells were grown on glycerol.

Several glycerol dehydrogenating enzymes from animal and microbiological sources have been purified by affinity chromatography using immobilized Cibacron Blue F3G-A (Flynn \& Cromlish, 1982; Ruch et al., 1980; Kawagishi et al., 1980; Viswanath-Reddy et al., 1978). However, the enzyme from $C$. valida was not inhibited by Blue Dextran 2000 and showed $85 \%$ of residual activity even in the presence of $0.1 \mathrm{~mm}$-Cibacron Blue F3G-A. Accordingly, attempts to bind the enzyme to Cibacron Blue-Sephadex G-100 failed. Similar behaviour was reported by Jervis \& Schmidt (1977) for potato lactate dehydrogenase.

Glycerol dehydrogenase from C. valida was shown to be a dimer consisting of subunits having an equal molecular weight. The enzyme was not capable of forming higher oligomers. In the course of the purification procedure the native enzyme always exhibited the same electrophoretic mobility in polyacrylamide gels. The enzyme did not appear heterogeneous when analysed by isoelectric focusing. The $\mathrm{NAD}^{+}$-linked isoenzymes of glycerol dehydrogenase from Geotrichum candidum were reported to be tetramers (Itoh, 1982). The aldose reductase from Rhodotorula was found to consist of two subunits being different in size and function (Sheys \& Doughty, 1971 a). Compared with the isoenzymes from $G$. candidum, which were completely inactive after heating at $50^{\circ} \mathrm{C}$ for $20 \mathrm{~min}$, the glycerol dehydrogenase from C. valida retained about $80 \%$ of its initial activity under these conditions.

The specific activity of the enzyme from $C$. valida for glycerol oxidation [448 units (mg protein $)^{-1}$ ] was significantly higher than reported in the literature for other glycerol dehydrogenases. The different conditions used to assay activity cannot account for these differences.

The higher affinity for 1,2-propanediol is not unusual and has also been observed for prokaryotic glycerol dehydrogenases (Lin, 1976; Tang et al., 1979; Yamada et al., 1982). Accordingly, substrate inhibition by 1,2-propanediol occurred at lower concentrations (above $100 \mathrm{mM}$ ) than with glycerol. No inhibition by dihydroxyacetone was found in the reverse reaction, as was described for the glycerol dehydrogenase from Aerobacter aerogenes (Strickland \& Miller, 1968) and Cellulomonas (Yamada et al., 1982). Furthermore, some similarity to the glycerol dehydrogenases from bacteria is apparent in the degree of activation of the enzymes by monovalent cations (Lin \& Magasanik, 1960; McGregor et al., 1974). A requirement for divalent cations as recently shown for the glycerol dehydrogenase from Bacillus megaterium (Scharschmidt et al., 1983) could not be established. Concerning the influence of anions, the enzyme from $C$. valida appeared different from the isoenzymes in $G$. candidum. Itoh (1982) reported an activation by chloride in the forward reaction and an inhibition by borate and phosphate. In contrast, chloride salts were less effective on the Candida enzyme, but multivalent anions, in particular pyrophosphate, showed the highest stimulating effect on the activity of the enzyme. For aldose reductase from $R$ hodotorula it was demonstrated that pyrophosphate affected competitively the association between the cofactor and the enzyme (Sheys \& Doughty, 1971b). This may also be true for the glycerol dehydrogenase from $C$. valida, where dissociation of NADH from the enzyme seems to be the rate-limiting step $\left(K_{\mathrm{i}}^{\mathrm{NADH}} 2.5 \times 10^{-5} \mathrm{M}\right)$.

Glycerol dehydrogenase from C. valida was inhibited by Tris, as is a similar enzyme from Microcyclus eburneus (Nishio et al., 1978); however, the isoenzymes from $G$. candidum apparently behaved differently (Itoh, 1982).

Studies on substrate specificity of the Candida enzyme revealed an absolute requirement for $\mathrm{NAD}^{+}$and $\mathrm{NADH}$. The identification of the oxidation product as dihydroxyacetone 
demonstrated that the enzyme attacked the internal carbon (C2) and was therefore a glycerol : NAD ${ }^{+}$2-oxidoreductase (EC 1.1.1.6). The enzyme showed higher specificity than the glycerol dehydrogenases from bacteria. Prokaryotic glycerol dehydrogenases exerted detectable activities on ethylene glycol and glycerol 3-phosphate (Burton, 1955; Hochuli et al., 1977; Yamada et al., 1982) and accepted NADPH as the dehydrogenase from Escherichia coli (Tang et al., 1979).

The inhibiting effect of 2-mercaptoethanol on glycerol dehydrogenase from C. valida could be due to a structural analogy to ethylene glycol. The fact that only slight inhibition was produced by dithiothreitol and cysteine suggests that the reduction of disulphide bridges is unlikely.

The significance of glycerol dehydrogenase for glycerol utilization in C. valida $\mathrm{H} 122$ becomes evident from the observation that it was subject to catabolite repression (Babel \& Hofmann, 1982). The relatively high $K_{\mathrm{m}}$ value for glycerol $(58 \mathrm{~mm})$ found for this enzyme matches the requirements of the cell because of the extremely high affinity of the subsequent kinase for dihydroxyacetone (Babel \& Hofmann, 1982). Moreover, a methylglyoxal synthase has been found in C. valida $\mathrm{H} 122$ (Babel \& Hofmann, 1981). In the presence of this enzyme the increased levels of dihydroxyacetone phosphate, which might occur with a glycerol dehydrogenase of lower $K_{\mathrm{m}}$, would give rise to a lethal concentration of methylglyoxal within the cell (Hofmann \& Babel, 1983). Therefore, the low-affinity pathway for glycerol utilization apparently prevents the formation of an excessive level of dihydroxyacetone phosphate which could lead to a toxic production of methylglyoxal.

The authors are indebted to Professor W. Babel and Dr K. H. Hofmann for their encouragement and generous support during this work, to Mrs E. Clauss and Mrs M. Pickert for some technical assistance and to Professor E. Hofmann for critical reading of the manuscript.

\section{REFERENCES}

ANDREws, P. (1964). Estimation of the molecular weights of proteins by Sephadex gel filtration. Biochemical Journal 91, 222-223.

Babel, W. \& HofmanN, K. H. (1981). The conversion of triosephosphate via methylglyoxal, a bypass to the glycolytic sequence in methylotrophic yeasts? FEMS Microbiology Letters 10, 133-136.

BABEL, W. \& HofmanN, K. H. (1982). The relation between the assimilation of methanol and glycerol in yeasts. Archives of Microbiology 132, 179-184.

BöHME, H.-J., KopperschläGER, G., SCHulz, J. \& HoFmanN, E. (1972). Affinity chromatography of phosphofructokinase using Cibacron blue F3G-A. Journal of Chromatography 69, 209-214.

BradFord, M. M. (1976). A rapid and sensitive method for the quantitation of microgram quantities of protein utilizing the principle of protein-dye binding. Analytical Biochemistry 72, 248-254.

BURTON, R. M. (1955). Glycerol dehydrogenase from Aerobacter aerogenes. Methods in Enzlmology 1, 397400.

Cleland, W. W. (1963). The kinetics of enzymecatalyzed reactions with two or more substrates or products. Biochimica et biophysica acta 67, 104-137.

Dunker, A. K. \& KenYon, A. J. (1976). Mobility of sodium dodecyl sulphate-protein complexes. Biochemical Journal 153, 191-197.

Eisenthal, R. \& CoRnish-Bowden, A. (1974). The direct linear plot. A new graphical procedure for estimating enzyme kinetic parameters. Biochemical Journal 139, 715-720.

FlynN, T. G. \& CRomlish, J. A. (1982). Glycerol dehydrogenase from rabbit muscle. Methods in Enzymology 89, 237-242.
Gancedo, C., Gancedo, J. M. \& Sols, A. (1968). Glycerol metabolism in yeasts: pathways of utilization and production. European Journal of Biochemistry 5, 165-172.

HANES, C. S. (1932). Studies on plant amylases. I. The effect of starch concentration upon the velocity of hydrolysis by the amylase of germinated barley. Biochemical Journal 26, 1406-1421.

Hochuli, E., Taylor, K. E. \& Dutler, H. (1977). Dihydroxyacetone reductase from Mucor javanicus. 2. Identification of the physiological substrate and reactivity towards related compounds. European Journal of Biochemistry 75, 433-439.

HofmanN, K. H. \& Babel, W. (1979). Synthese und Akkumulation der Glycerin-Dehydrogenase in Candida valida $\mathrm{H} 122$ in Abhängigkeit von der C-Quelle. VII. Reinhardsbrunner Symposium der Sektion Mikrobiologie der Biologischen Gesellschaft der DDR, vom 6. bis 12. Mai. In Abhandlungen der Akademie der Wissenschaften der DDR N3, pp. 229-234. Berlin: Akademie-Verlag 1981

Hofmann, K. H. \& Babel, W. (1983). Methylglyoxal ein toxisches Fermentationsprodukt. Acta Biotechnologica 3, 21-25.

IтоH, N. (1982). Purification and characterization of glycerol dehydrogenase isoenzymes from Geotrichum candidum. Agricultural and Biological Chemistry 46, 3029-3039.

JERVIS, L. \& SCHMIDT, C. N. G. (1977). Affinity chromatography of potato lactate dehydrogenase. Biochemical Society Transactions 5, 1767-1770.

KaWAGishi, T., Nishio, N., Matsuno, R. \& KamiKUBo, T. (1980). Purification of NAD-dependent 1,2-propanediol dehydrogenating enzyme from 
Microcyclus eburneus. Agricultural and Biological Chemistry 44, 949-950.

KoIKe, M. \& Hamada, M. (1971). Preparation of calcium phosphate gel deposited on cellulose. Methods in Enzymology 22, 339-342.

Kopperschlä GER, G., STORCH, H. \& Birkenmeier, G. (1977). Einsatz der Porengradienten-Polyacrylamidgelelektrophorese zur Diagnostik von Paraproteinämien. Zeitschrift für medizinische Laboratoriumsdiagnostik 18, 300-308.

LaAs, T. \& Fast-Johansson, A. (1979). Isoelectric focusing with Pharmalyte in gel rods. In Protides of Biological Fluids. 27th Colloquium, pp. 693-697. Edited by H. Peeters. Oxford: Pergamon Press.

LIN, E. C. C. (1976). Glycerol dissimilation and its regulation in bacteria. Annual Review of Microbiology 30, 535-578.

Lin, E. C. C. \& Magasanik, B. (1960). The activation of glycerol dehydrogenase from Aerobacter aerogenes by monovalent cations. Journal of Biological Chemistry 235, 1820-1823.

MAY, J. W. \& SLOAN, J. (1981). Glycerol utilization by Schizosaccharomyces pombe: dehydrogenation as the initial step. Journal of General Microbiology 123, 183185.

May, J. W., Marshall, J. H. \& Sloan, J. (1982). Glycerol utilization by Schizosaccharomyces pombe: phosphorylation of dihydroxyacetone by a specific kinase as the second step. Journal of General Microbiology 128, 1763-1766.

McGregor, W. G., Phillips, J. \& Suelter, C. H. (1974). Purification and kinetic characterization of a monovalent cation-activated glycerol dehydrogenase from Aerobacter aerogenes. Journal of Biological Chemistry 249, 3132-3139.

Nishio, N.. Kawagishi, T., Matsuno, R. \& Kami KUBO, T. (1978). Metabolism of 1,2-propanediol by methanol-utilizing bacteria and some properties of 1,2-propanediol dehydrogenating enzyme. Agricultural and Biological Chemistry 42, 1095-1100.

READER, V. (1927). The relation of the growth of certain micro-organisms to the composition of the medium. I. The synthetic culture medium. Biochemical Journal 21, 901-907.

RuCh, F. E., Lin, E. C. C., Kowit, J. D., TANG, C. -T. \& GoldberG, A. L. (1980). In-vivo inactivation of glycerol dehydrogenase in Klebsiella aerogenes: properties of active and inactivated proteins. Journal of Bacteriology 141, 1077-1085.

Scharschmidt, M., Pfleiderer, G., Metz, H. \& BR ÜMMER, W. (1983). Isolierung und Charakterisierung von Glycerin-Dehydrogenase aus Bacillus megaterium. Zeitschrift für physiologische Chemie 364, 911 921.

SCRIMGEOUR, K. G. (1977). Molecular weight. In Chemistry and Control of Enzyme Reactions, pp. 14 16. London: Academic Press.

SELWYN, M. J. (1965). A simple test for inactivation of an enzyme during assay. Biochimica et biophysica acta 105, 193-195.

SheYs, G. H. \& DoughtY, C. C. (1971a). Subunits of aldose reductase from Rhodotorula. Biochimica et biophysica acta 235, 414-417.

Sheys, G. H. \& Doughty, C. C. (1971b). The reaction mechanism of aldose reductase from Rhodotorula. Biochimica et biophysica acta 242, 523-531.

Sprague, G. F. \& Cronan, J. E. (1977). Isolation and characterization of Saccharomyces cerevisiae mutants defective in glycerol catabolism. Journal of Bacteriology 129, 1335-1342.

Strickland, J. E. \& Miller, O. N. (1968). Inhibition of glycerol dehydrogenase from Aerobacter aerogenes by dihydroxyacetone, high ionic strength, and monovalent cations. Biochimica et biophysica acta 159 , 221-226.

TANG, C. - T., Ruch, F. E. \& Lin, E. C. C. (1979). Purification and properties of a nicotinamide adenine dinucleotide-linked dehydrogenase that serves an Escherichia coli mutant for glycerol catabolism. Journal of Bacteriology 140, 182-187.

Viswanath-Reddy, M., Pyle, J. E. \& Howe, H. B. (1978). Purification and properties of NADP+. linked glycerol dehydrogenase from Neurospora crassa. Journal of General Microbiology 107, 289-296.

WEBER, K. \& OSBORN, M. (1969). The reliability of molecular weight determinations by dodecyl sulfatepolyacrylamide gel electrophoresis. Journal of Biological Chemistry 244, 4406-4412.

Yamada, H., Nagao, A., Nishise, H. \& Tani, Y. (1982). Glycerol dehydrogenase from Cellulomonas sp. NT3060: purification and characterization. Agricultural and Biological Chemistry 46, 2333-2339. 